\title{
Kinetic and Mechanistic Studies on the Interaction of Glycyl-L-alanine, Glycyl-L-asparagine, and Glycyl-L-tyrosine with Hydroxopentaaquarhodium(III) Ion
}

\author{
Biplab K. Bera, Sumon Ray, Subala Mondal, Parnajyoti Karmakar, Arup Mandal, \\ Subhasis Mallick, and Alak K. Ghosh \\ Department of Chemistry, The University of Burdwan, Burdwan, West Bengal 713104, India \\ Correspondence should be addressed to Alak K. Ghosh; alakghosh2002@yahoo.co.in
}

Received 13 May 2013; Accepted 12 July 2013

Academic Editor: Antonio Manuel Romerosa-Nievas

Copyright (c) 2013 Biplab K. Bera et al. This is an open access article distributed under the Creative Commons Attribution License, which permits unrestricted use, distribution, and reproduction in any medium, provided the original work is properly cited.

\begin{abstract}
The kinetics of the interaction of three glycine-containing dipeptides, namely, glycyl-L-alanine $\left(\mathrm{L}^{1}-\mathrm{L}^{\prime} \mathrm{H}\right)$, glycyl-L-asparagine ( $\mathrm{L}^{2}$ $\left.\mathrm{L}^{\prime} \mathrm{H}\right)$, and glycyl-L-tyrosine $\left(\mathrm{L}^{3}-\mathrm{L}^{\prime} \mathrm{H}\right)$ with $\left[\mathrm{Rh}\left(\mathrm{H}_{2} \mathrm{O}\right)_{5} \mathrm{OH}\right]^{2+}$ has been studied spectrophotometrically in aqueous medium as a function of the molar concentration of $\left[\mathrm{Rh}\left(\mathrm{H}_{2} \mathrm{O}\right)_{5} \mathrm{OH}\right]^{2+}$, [dipeptide], $\mathrm{pH}$, and temperature at constant ionic strength. Reactions were studied at $\mathrm{pH} 4.3$, where the substrate complex exists predominantly as the hydroxopentaaqua species and dipeptides as the zwitterion. The reaction has been found to proceed via two parallel paths: both processes are ligand dependent. The rate constant for the processes are $k_{1} \sim 10^{-3} \mathrm{~s}^{-1}$ and $k_{2} \sim 10^{-5} \mathrm{~s}^{-1}$. The activation parameters for both the steps were evaluated using Eyring's equation. The low $\Delta H_{1}^{\neq}$and large negative value of $\Delta S_{1}^{\neq}$as well as $\Delta H_{2}^{\neq}$and $\Delta S_{2}^{\neq}$indicate an associative mode of activation for both the aqua ligand substitution processes for both the parallel paths. The product of the reaction has been characterized by IR and ESI-mass spectroscopic analyses.
\end{abstract}

\section{Introduction}

The continued interest in platinum-based antitumor compounds is stimulated by the fact that certain tumors are resistant to the clinically used drugs cis-platin and carboplatin. As work progressed, different $\mathrm{Pt}(\mathrm{II})$ amine complexes and their derivatives as well as complexes of other $4 \mathrm{~d}$ and $5 \mathrm{~d}$ metal ions with nucleic acid constituents $[1,2]$ were studied. Complexes of other metal ions specially ruthenium, rhodium, iridium, and palladium have also been reported to have considerable antibacterial power [3-5]. It is reported that ruthenium complexes are an order of magnitude less toxic than cis-platin [6,7]. The novel rhodium(III) and iridium(III) complexes are characterized as potential anticancer agents in respect to their cytotoxicity [8]. Meridional rhodium(III) polypyridyl complexes of the type mer-[RhX $\left.{ }_{3}(\mathrm{DMSO})(\mathrm{pp})\right]$ $(\mathrm{X}=\mathrm{Cl}, \mathrm{pp}=$ phen, dpq, dppz; $\mathrm{X}=\mathrm{Br}, \mathrm{pp}=$ phen $)$ represent a promising class of potent cytostatic agents for the treatment of lymphoma and leukemia [9].
It is now established [10] that cis-platin at first hydrolyses in the biological condition and the aqua variety is the active species. Some of the hydrolyzed products are also responsible for toxicity. Thus, it is expected that aqua complexes if used directly will be less toxic. In order to examine the bioactivity of rhodium(III) complexes, studies on the interaction of rhodium(III) with pyridine-2-aldoxime [11], DL-methionine [12], L-cysteine [13], and adenosine [14] have already been reported. In the present paper we report the results on the interaction of three glycine containing dipeptides glycyl-Lalanine $\left(\mathrm{L}^{1}-\mathrm{L}^{\prime} \mathrm{H}\right)$, glycyl-L-aspergine $\left(\mathrm{L}^{2}-\mathrm{L}^{\prime} \mathrm{H}\right)$ and glycyl-Ltyrosine $\left(L^{3}-L^{\prime} H\right)$ with the title complex. Obtained results are investigated for the kinetic tuning of the interaction of such ligands via electronic and steric effects. This work describes the detailed kinetic and mechanistic studies of aqua ligand substitution from hydroxopentaaquarhodium(III) ion by the dipeptide which is a model dipeptide. This work is also interesting from kinetic view point because of its parallel reaction paths. 


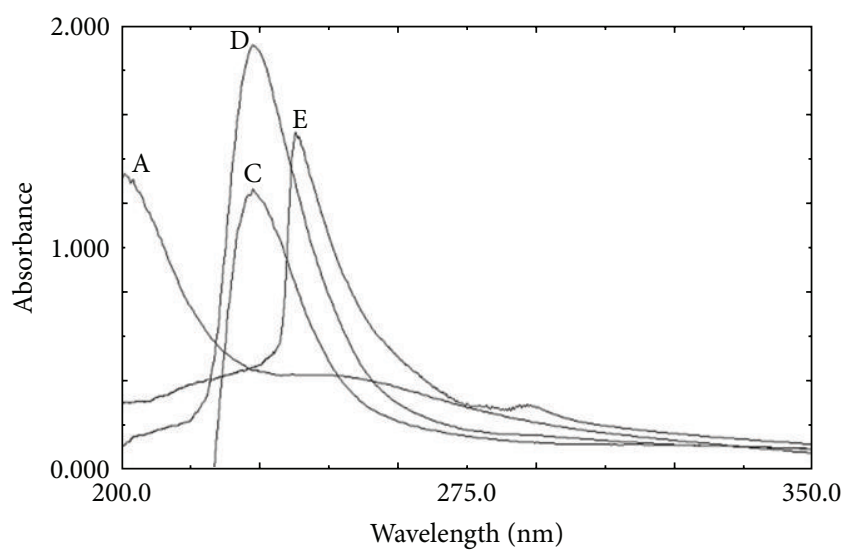

FIGURE 1: Spectra of the starting complex (A), glycyl-L-alanine $\left(L^{1}-L^{\prime} H\right)$ substituted complex $(\mathbf{C})$, glycyl-L-aspergine $\left(L^{2}-L^{\prime} H\right)$ substituted complex $(D)$, and glycyl-L-tyrosine $\left(\mathrm{L}^{3}-\mathrm{L}^{\prime} \mathrm{H}\right)$ substituted complex (E); [complex A] $=2.5 \times 10^{-4} \mathrm{~mol} \mathrm{dm}^{-3}$, [dipeptide] $=7.5 \times$ $10^{-3} \mathrm{~mol} \mathrm{dm}{ }^{-3}, \mathrm{pH}=4.3$, cell used $=1 \mathrm{~cm}$ quartz.

\section{Experimental}

$\left[\mathrm{Rh}\left(\mathrm{H}_{2} \mathrm{O}\right)_{6}\right]\left(\mathrm{ClO}_{4}\right)_{3}$ was prepared as per the literature method [15] and characterized by chemical analysis and spectroscopic data [16] $\left(\lambda_{\max }=396 \mathrm{~nm}, \varepsilon=62 \mathrm{dm}^{3} \mathrm{~mol}^{-1} \mathrm{~cm}^{-1}\right.$; $\left.\lambda_{\max }=311 \mathrm{~nm}, \varepsilon=67.4 \mathrm{dm}^{3} \mathrm{~mol}^{-1} \mathrm{~cm}^{-1}\right)$. The reactant complex $\left[\mathrm{Rh}\left(\mathrm{H}_{2} \mathrm{O}\right)_{5}(\mathrm{OH})\right]\left(\mathrm{ClO}_{4}\right)_{2}$ [complex A] was obtained in situ (yield 90\%) by adjusting the $\mathrm{pH}$ to 4.3 . Higher proportions of complex could not be obtained as the solution becomes turbid at higher $\mathrm{pH}$. The reaction product of dipeptides and complex $\mathbf{A}$ was (substituted complex: complex $\mathbf{C}$, complex $\mathbf{D}$, and complex $\mathbf{E}$ ) prepared by mixing the reactants in different ratios, namely, $1: 1,1: 2,1: 3,1: 5$, and $1: 10$, and equilibrating the mixtures at $60^{\circ} \mathrm{C}$ for $72 \mathrm{~h}$. The absorption spectra of all these mixtures (Figure 1) for each of complex $\mathbf{C}$, complex $\mathbf{D}$, and complex $\mathbf{E}$ show identical $\lambda_{\max }$ with almost same absorbance indicating the complete complexation. But $\lambda_{\max }$ for complex C-E are $224 \mathrm{~nm}, 226 \mathrm{~nm}$, and $239 \mathrm{~nm}$, respectively.

2.1. Product Analysis. The composition of the product in the reaction mixture was determined by Job's method of continuous variation (Figure 2). The metal-ligand ratio was found to be $2: 1$.

$\left[\mathrm{Rh}\left(\mathrm{H}_{2} \mathrm{O}\right)_{5}(\mathrm{OH})\right]^{2+}$ and dipeptides were mixed in $2: 1$ molar ratio at $\mathrm{pH} 4.3$, and the products were obtained. The IR spectra of all the product complexes, in the $\mathrm{KBr}$ disc, show strong bands in the region $\sim 3414-3094 \mathrm{~cm}^{-1}$, together with medium bands at 1609,559 , and $398 \mathrm{~cm}^{-1}$. The asymmetric $-\mathrm{COO}^{-}$stretching frequency $\left(v_{\text {asym }}\right)$ of the zwitterionic forms of amino acids occurs at $1580-1660 \mathrm{~cm}^{-1}$ when the group is coordinated to metals, where as a noncoordinated $-\mathrm{COO}^{-}$group has the $v_{\text {asym }}\left(\mathrm{COO}^{-}\right)$stretching at lower frequency [17]. The band at $1609 \mathrm{~cm}^{-1}$ is therefore due to the $v_{\text {asym }}\left(\mathrm{COO}^{-}\right)$of the metal bound carboxyl group. The presence of strong stretching band at $\sim 3414 \mathrm{~cm}^{-1}$ indicates that the product contains aqua or hydroxyl ligands.

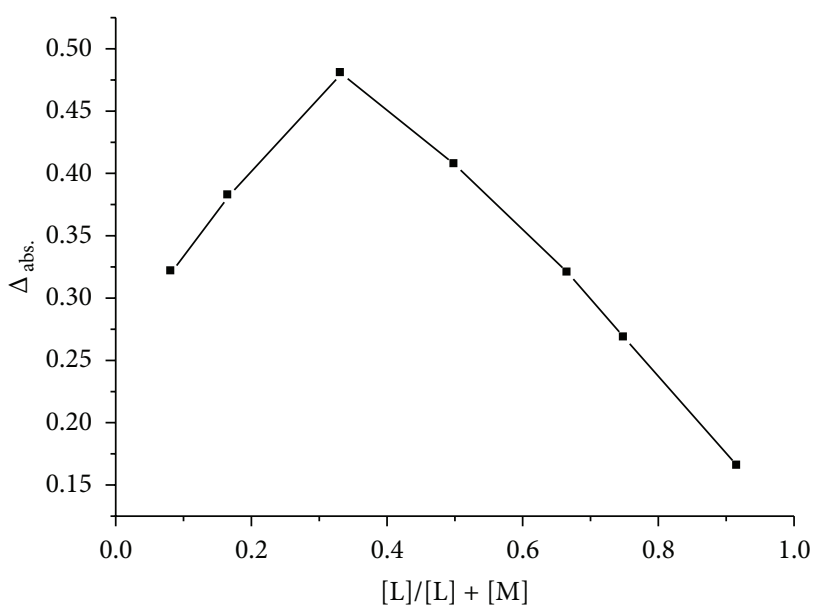

FIGURE 2: Job's plot for reaction of complex A with glycyl-L-alanine $\left(\mathrm{L}^{1}-\mathrm{L}^{\prime} \mathrm{H}\right)$ at the wavelength $224 \mathrm{~nm}$.

The bands at 559 and $398 \mathrm{~cm}^{-1}$ are assigned to $\nu(\mathrm{Rh}-\mathrm{N})$ and $\nu(\mathrm{Rh}-\mathrm{O})$ bond formation, respectively [18]. An intense band of the $\nu(\mathrm{C}=\mathrm{O})_{\text {amide }}$ at $1693 \mathrm{~cm}^{-1}$ in the noncoordinated peptide undergoes a bathochromic shift of $\sim 84 \mathrm{~cm}^{-1}$ in the IR spectrum upon complexation. This is probably due to the involvement of the peptide nitrogen (because of the deprotonation that has taken place) in bonding with $\mathrm{Rh}(\mathrm{III})$, which lowers the bond order of the $v(\mathrm{C}=\mathrm{O})_{\text {amide }}$ group due to resonance stabilization.

The aqueous solution's of $\left[\mathrm{Rh}\left(\mathrm{H}_{2} \mathrm{O}\right)_{5}(\mathrm{OH})\right]^{2+}$ and glycyl$\mathrm{L}$-alanine $\left(\mathrm{L}^{1}-\mathrm{L}^{\prime} \mathrm{H}\right)$ were mixed in a $2: 1$ molar ratio, and the mixture was thermostated at $60^{\circ} \mathrm{C}$ for 48 hours and used for ESI-MS measurement. The ESI mass spectra of the resulting solution are shown in Figure 3.

It is clear from this spectrum that the ion at $m / z 246.18$ (minor peak) has become the parent ion species in the mixture solution, and this is tentatively attributed to (glycylL-alanine $\left.+2 \mathrm{Rh}^{3+}+6 \mathrm{H}_{2} \mathrm{O}+2 \mathrm{HO}^{-}\right)^{2+}$. The parent ion is shown in Figure 4.

\section{Measurements}

All the spectral scanning and kinetic measurements were done in a Shimadzu UV-VIS spectrophotometer (UV-2450 $\mathrm{PC}$ ), with a thermoelectric cell temperature controller (model TCC-240A with an accuracy of $\pm 0.1^{\circ} \mathrm{C}$ ). IR spectra ( $\mathrm{KBr}$ disc, $4000-300 \mathrm{~cm}^{-1}$ ) were measured in Perkin-Elmer FTIR model RX1 infrared Spectrophotometer. ESI-mass spectra were recorded using a micromass Q-Tof micromass spectrometer in positive ion mode. The $\mathrm{pHs}$ of the solutions were adjusted with $\mathrm{HClO}_{4} / \mathrm{NaOH}$ and measured with a Sartorius $\mathrm{pH}$ meter (model PB11) with an accuracy of \pm 0.01 .

The progress of the reaction was monitored by the absorbance measurements at different intervals of time with a Shimadzu spectrophotometer (UV-2450 PC) attached to a thermoelectric cell temperature controller (TCC-240A) at $224 \mathrm{~nm}$. The conventional mixing technique was followed, and pseudo first order conditions were employed throughout. 


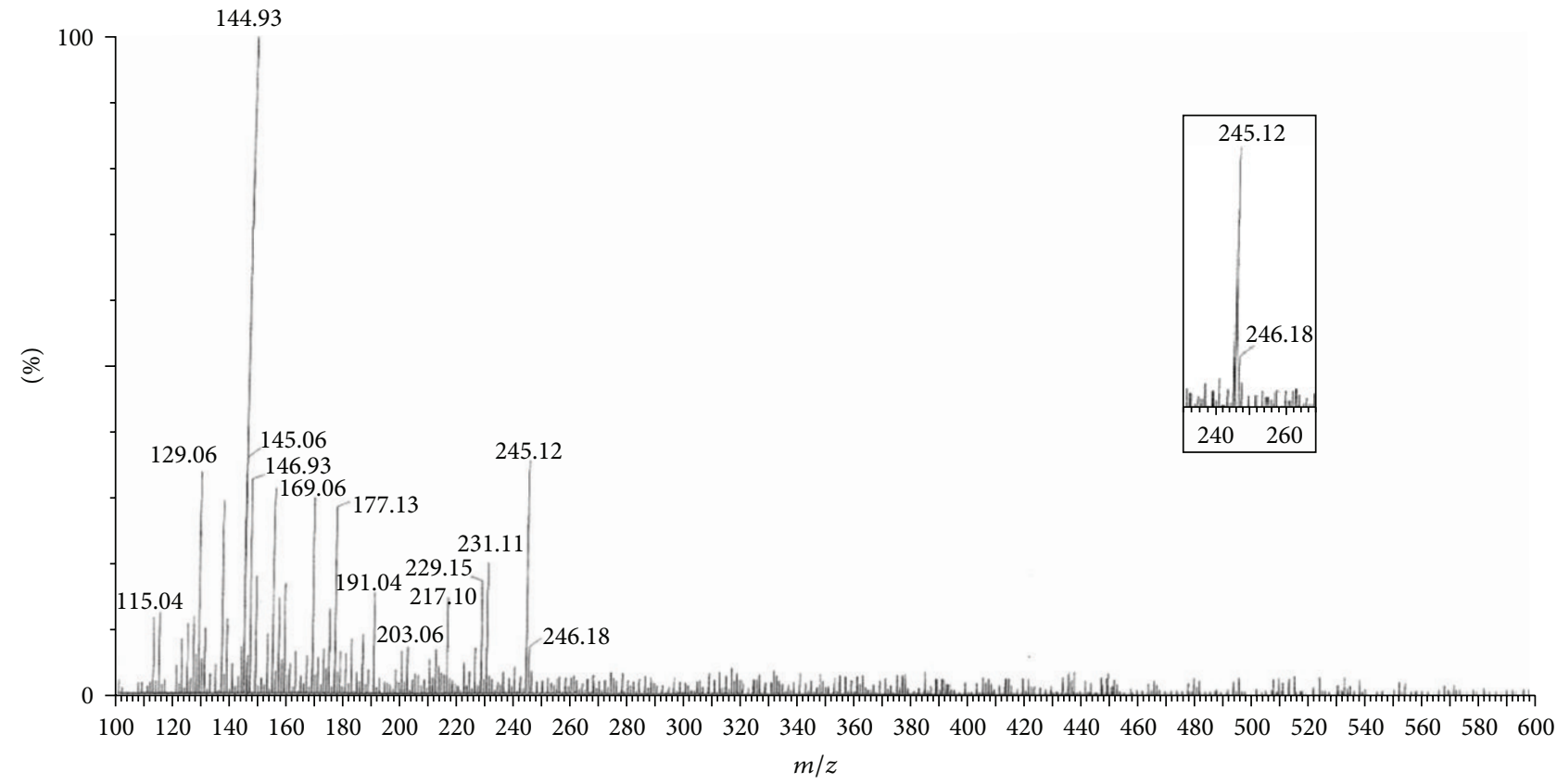

FIGURE 3: ESI-mass spectrum of the substituted hydroxopentaaquarhodium(III) ion by glycyl-L-alanine.

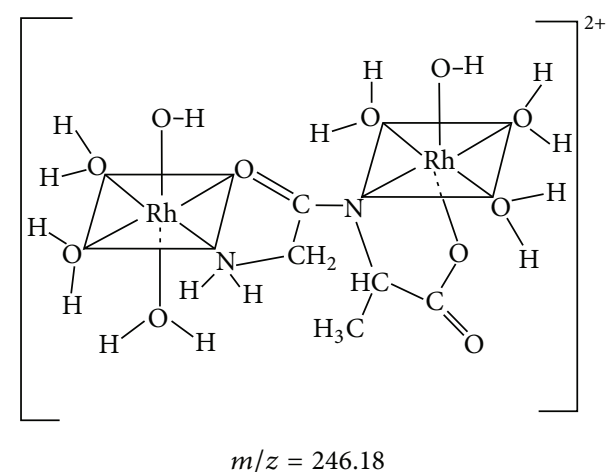

FIgURE 4: Plausible structure of the parent ion from the ESI-mass spectrum.

The plots of $\ln \left(A_{\infty}-A_{t}\right)$ (where $A_{t}$ and $A_{\infty}$ are absorbance at time $t$ and at infinite time or after the completion of the reaction) against time (Figure 5) were found to be nonlinear, curved at the initial stage and subsequently linear in nature indicating that the reactions proceed via two steps mechanism. From the limiting linear portion of the curve, the values of $k_{2(\mathrm{obs})}$ were obtained. The $k_{1(\mathrm{obs})}$ values were obtained from the slopes of $\ln \Delta$ (the meaning of $\Delta$ is shown in Figure 5) versus time when $t$ is small (Figure 6). The reported rate data represented as an average of duplicate runs were reproducible within $\pm 4 \%$.

\section{Results and Discussion}

From the $\mathrm{p} K_{a}$ values [19] of the dipeptides, it is clear that, at $\mathrm{pH} 4.3$, the major species involved in the kinetic processes are the zwitterionic forms of the dipeptides.

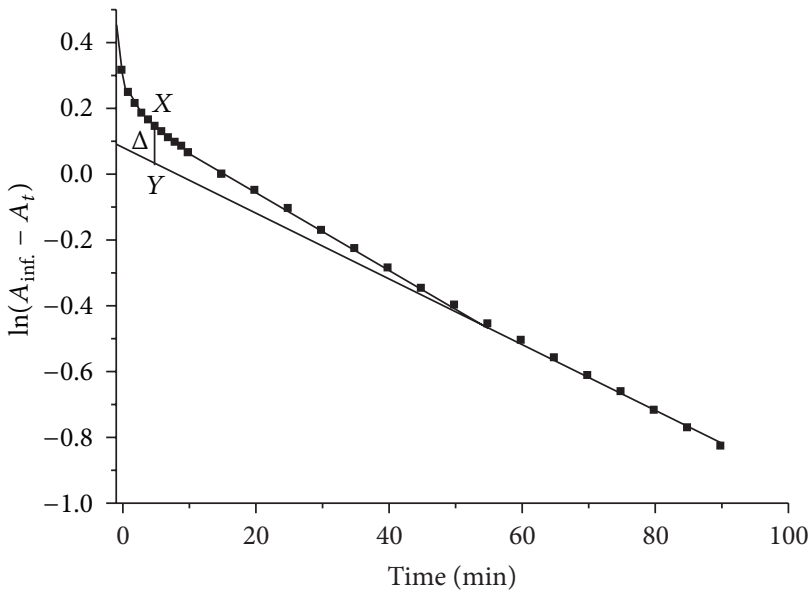

FIgURE 5: A typical plot of $\ln \left(A_{\infty}-A_{t}\right)$ versus time. $[$ complex $\mathbf{A}]=$ $2.5 \times 10^{-4} \mathrm{~mol} \mathrm{dm}{ }^{-3},\left[\mathrm{~L}^{1}-\mathrm{L}^{\prime} \mathrm{H}\right]=7.5 \times 10^{-3} \mathrm{~mol} \mathrm{dm}^{-3}, \mathrm{pH}=4.3$, and temperature $=60^{\circ} \mathrm{C} ; \Delta=X-Y$ is difference in absorbances between two steps at different time interval.

On the other hand, the ionization of $\left[\mathrm{Rh}\left(\mathrm{H}_{2} \mathrm{O}\right)_{6}\right]^{3+}$ may be given as

$$
\begin{gathered}
{\left[\mathrm{Rh}\left(\mathrm{H}_{2} \mathrm{O}\right)_{6}\right]^{3+} \stackrel{K_{c(1)}}{\rightleftharpoons}\left[\mathrm{Rh}\left(\mathrm{H}_{2} \mathrm{O}\right)_{5} \mathrm{OH}\right]^{2+}+\mathrm{H}^{+}} \\
{\left[\mathrm{Rh}\left(\mathrm{H}_{2} \mathrm{O}\right)_{5} \mathrm{OH}\right]^{2+} \stackrel{K_{c(2)}}{\rightleftharpoons}\left[\mathrm{Rh}\left(\mathrm{H}_{2} \mathrm{O}\right)_{4}(\mathrm{OH})_{2}\right]^{+}+\mathrm{H}^{+} .}
\end{gathered}
$$

The $\mathrm{p} K_{c(1)}$ and $\mathrm{p} K_{c(2)}$ values of $\left[\mathrm{Rh}\left(\mathrm{H}_{2} \mathrm{O}\right)_{6}\right]^{3+}$ are 3.6 and 4.7 , respectively, at $25^{\circ} \mathrm{C}$ [20]. Other reports on the $\mathrm{p} K_{c(1)}$ value are $3.2,3.4$, and 3.45 (references are given in [20]). With an increase in $\mathrm{pH}$, the proportion of the more labile 


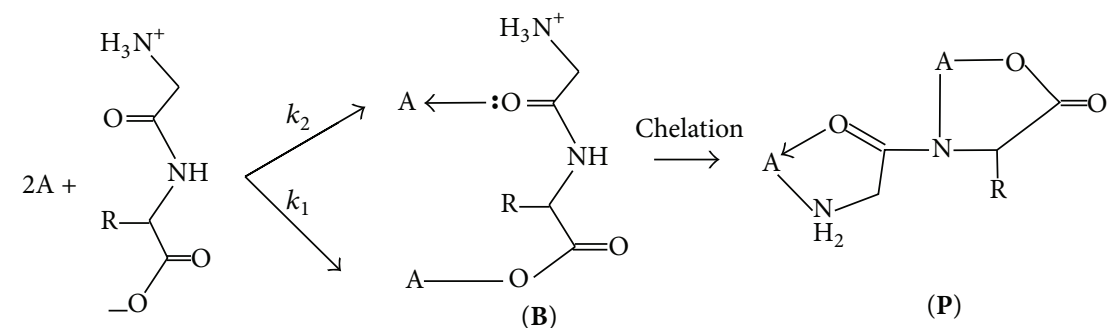

SCHEME 1

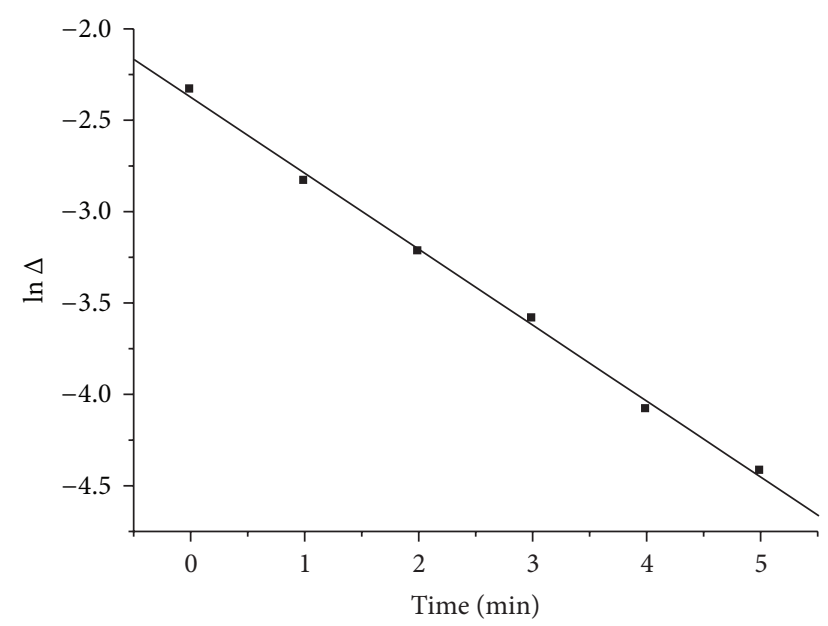

Figure 6: Plot of $\ln \Delta$ versus time. [complex $\mathbf{A}$ ] $=2.5 \times$ $10^{-4} \mathrm{moldm}^{-3},\left[\mathrm{~L}^{1}-\mathrm{L}^{\prime} \mathrm{H}\right]=7.5 \times 10^{-3} \mathrm{~mol} \mathrm{dm}^{-3}, \mathrm{pH}=4.3$, and temperature $=60^{\circ} \mathrm{C}$.

hydroxopentaaquarhodium(III) ion increases. The hydroxide ligand increases the water exchange rate of $\left[\mathrm{Rh}\left(\mathrm{H}_{2} \mathrm{O}\right)_{5} \mathrm{OH}\right]^{2+}$ relative to $\left[\mathrm{Rh}\left(\mathrm{H}_{2} \mathrm{O}\right)_{6}\right]^{3+}$. In the studied $\mathrm{pH}$ range, dipeptides exist mainly as the dipolar ion. As the $\mathrm{pH}$ increases, the proportion of the more reactive anionic form increases, and since the ligating capability of the deprotonated ligand is always higher than its dipolar ion form, the rate increases with $\mathrm{pH}$ as expected. The $\mathrm{pH}$ range chosen in the present study is 3.0 to 4.3 , where the active species involved in the reaction is $\mathrm{L}^{1}-\mathrm{L}^{\prime} \mathrm{H}$. At $\mathrm{pH}$ higher than 4.5, precipitation of $\mathrm{Rh}^{3+}$ takes place.

At constant temperature, $\mathrm{pH}$ (4.3), and fixed concentration of complex (A), the $\ln \left(A_{\infty}-A_{t}\right)$ versus time $(t)$ plot for different ligand concentrations indicates a two-step process. Both are dependent on the incoming ligand concentration, and with increasing ligand concentration, a limiting rate is observed. Job's method of complexation indicates a $2: 1$ metal-ligand ratio in the product complex. This is possible only when a bridged complex is formed. The rate constant for such a process can be evaluated assuming Scheme 1, where, $\mathrm{L}$, the ligand reacts with both of the Rh centers [(1) and (2)] in a parallel fashion. In the starting complex, there are two equivalent rhodium(III) centers. Now, the ligand has two donor centers. As rhodium(III) is a borderline center, during the ligation, two donor centers attack in two parallel speeds $\left(k_{1} \sim 10^{-3} \mathrm{~s}^{-1}\right.$ and $\left.k_{2} \sim 10^{-5} \mathrm{~s}^{-1}\right)$, which is shown in Section 5 .

4.1. Calculation of $k_{1}$ Value for the $\boldsymbol{A} \rightarrow \boldsymbol{B}$ Step. The rate constant for the first phase of the reaction $\mathbf{A} \rightarrow \mathbf{B}$ was calculated from the absorbance data using the Weyh and Hamm [21] equation

$$
\left(A_{\infty}-A_{t}\right)=a_{1} \exp \left(-k_{1(\mathrm{obs})} t\right)+a_{2} \exp \left(-k_{2(\mathrm{obs})} t\right),
$$

where $a_{1}$ and $a_{2}$ are constants that depend upon the rate constants and extinction coefficients.

Values of $a_{2} \exp \left(-k_{2(\mathrm{obs})} t\right)$ at different times (when $t$ is small) were obtained from the linear portion of the curve (Figure 5) extended to $t$ equals zero; that is,

$$
a_{2} \exp \left(-k_{2(\mathrm{obs})} t\right)=\left(A_{\infty}-A_{t}\right)_{\text {limiting }} .
$$

Therefore, values of $\left(A_{\infty}-A_{t}\right)-a_{2} \exp \left(-k_{2(\mathrm{obs})} t\right)$ were calculated from $X$ and $Y$ values (Figure 5) at different $t$;

$$
\Delta=a_{1} \exp \left(-k_{1(\mathrm{obs})} t\right)
$$

or

$$
\ln \Delta=\text { constant }-k_{1(\mathrm{obs})} t .
$$

A similar procedure was applied for each ligand concentration in the $2.50 \times 10^{-3} \mathrm{~mol} \mathrm{dm}^{-3}$ to $7.50 \times 10^{-3} \mathrm{~mol} \mathrm{dm}^{-3}$ range using the experimental conditions specified in Table 1. The $k_{1(\mathrm{obs})}$ values were collected in Table 1.

The rate increases with an increase in $\left[\mathrm{L}^{1}-\mathrm{L}^{\prime} \mathrm{H}\right]$ and reaches a limiting value (Figure 7). The limiting rate is probably due to the completion of outer-sphere association complex formation. Since the metal ion reacts with its immediate environment, further change in $\left[L^{1}-L^{\prime} H\right]$ beyond the saturation point will not affect the reaction rate. The outer-sphere association complex may be stabilized through H-bonding $[25,26]$.

Based on the experimental findings, the following (6) and (7) may be proposed for the step $\mathbf{A} \rightarrow \mathbf{B}$ :

$$
\mathbf{A}+\left(\mathrm{L}-\mathrm{L}^{\prime} \mathrm{H}\right)+\mathbf{A} \stackrel{K_{E}, K_{E}^{\prime}}{\rightleftharpoons} \mathbf{A} \cdot\left(\mathrm{L}-\mathrm{L}^{\prime} \mathrm{H}\right) \cdot \mathbf{A} .
$$

Outer-sphere association complex

$$
\mathbf{A} \cdot\left(\mathrm{L}-\mathrm{L}^{\prime} \mathrm{H}\right) \cdot \mathbf{A} \stackrel{k_{1}}{\longrightarrow} \mathbf{B}(\mathbf{R h}(\mathbf{1})) .
$$


TABLE 1: $10^{3} k_{1(\mathrm{obs})}\left(\mathrm{s}^{-1}\right)$ values for different dipeptide concentrations at different temperatures; [Complex A] $=2.5 \times 10^{-4} \mathrm{~mol} \mathrm{dm}^{-3}, \mathrm{pH}=4.3$, ionic strength $=0.1 \mathrm{~mol} \mathrm{dm}^{-3} \mathrm{NaClO}_{4}$.

\begin{tabular}{|c|c|c|c|c|c|c|}
\hline \multirow{2}{*}{ Ligand } & \multirow{2}{*}{ Temperature $\left({ }^{\circ} \mathrm{C}\right)$} & \multicolumn{5}{|c|}{$10^{3}$ [Ligand] $\left(\mathrm{mol} \mathrm{dm}^{-3}\right)$} \\
\hline & & 2.50 & 3.75 & 5.00 & 6.25 & 7.50 \\
\hline \multirow{4}{*}{$L^{1}-L^{\prime} H$} & 50 & 2.23 & 2.77 & 3.07 & 3.37 & 3.69 \\
\hline & 55 & 2.75 & 3.32 & 3.81 & 4.14 & 4.33 \\
\hline & 60 & 3.19 & 3.95 & 4.42 & 4.47 & 5.15 \\
\hline & 65 & 3.77 & 4.67 & 5.16 & 5.62 & 6.09 \\
\hline \multirow{4}{*}{$L^{2}-L^{\prime} H$} & 50 & 0.52 & 0.69 & 0.81 & 0.92 & 1.01 \\
\hline & 55 & 0.72 & 0.93 & 1.10 & 1.23 & 1.35 \\
\hline & 60 & 0.98 & 1.28 & 1.47 & 1.64 & 1.82 \\
\hline & 65 & 1.27 & 1.59 & 1.85 & 2.08 & 2.27 \\
\hline \multirow{4}{*}{$L^{3}-L^{\prime} H$} & 50 & 1.53 & 1.90 & 2.15 & 2.33 & 2.46 \\
\hline & 55 & 2.03 & 2.49 & 2.83 & 3.05 & 3.15 \\
\hline & 60 & 2.57 & 3.11 & 3.45 & 3.66 & 3.80 \\
\hline & 65 & 3.21 & 3.83 & 4.27 & 4.52 & 4.69 \\
\hline
\end{tabular}

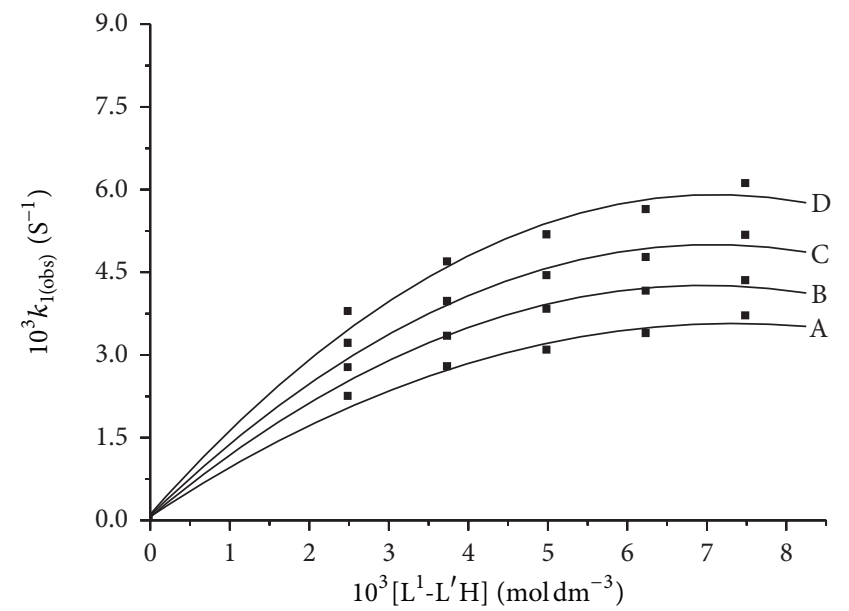

Figure 7: Plots of $k_{1(\mathrm{obs})}\left(\mathrm{s}^{-1}\right)$ versus $\left[\mathrm{L}^{1}-\mathrm{L}^{\prime} \mathrm{H}\right]$ at different temperatures, $\mathrm{A}=50, \mathrm{~B}=55, \mathrm{C}=60$, and $\mathrm{D}=65^{\circ} \mathrm{C}$.

Based on the above scheme, a rate expression can be derived for the $\mathbf{A} \rightarrow \mathbf{B}$ step

$$
\frac{d[\mathbf{B}]}{d t}=\frac{k_{1} K_{E}\left[\mathrm{Rh}\left(\mathrm{H}_{2} \mathrm{O}\right)_{5}(\mathrm{OH})^{2+}\right]_{T}[\text { dipeptide }]}{\left(1+K_{E}[\text { dipeptide }]\right)},
$$

or

$$
\frac{d[\mathbf{B}]}{d t}=k_{1(\mathrm{obs})}\left[\left[\mathrm{Rh}\left(\mathrm{H}_{2} \mathrm{O}\right)_{5}(\mathrm{OH})\right]^{2+}\right]_{T},
$$

where $T$ stands for total concentration of $\mathrm{Rh}$ (III). We can then write

$$
k_{1(\mathrm{obs})}=\frac{k_{1} K_{E}[\text { dipeptide }]}{1+K_{E}[\text { dipeptide }]},
$$

where $k_{1}$ is the rate constant for the $\mathbf{A} \rightarrow \mathbf{B}$ step, that is, the rate constant for the interchange of outer-sphere complex to the inner-sphere complex; $K_{E}$ is the outer-sphere association equilibrium constant.

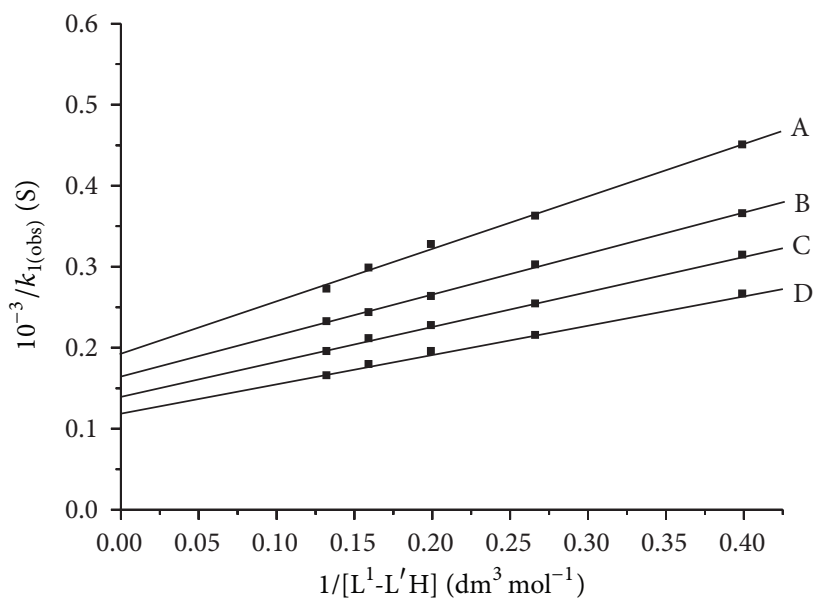

Figure 8: Plot of $1 / k_{1(\mathrm{obs})}(\mathrm{s})$ versus $1 /\left[\mathrm{L}^{1}-\mathrm{L}^{\prime} \mathrm{H}\right], \mathrm{A}=50, \mathrm{~B}=55$, $\mathrm{C}=60$, and $\mathrm{D}=65^{\circ} \mathrm{C}$.

The equation can be represented as

$$
\frac{1}{k_{1}(\mathrm{obs})}=\frac{1}{k_{1}}+\frac{1}{\left.k_{1} K_{E} \text { [dipeptide }\right]} \text {. }
$$

The plot of $1 / k_{1 \text { (obs) }}$ against $1 /$ [dipeptide] should be linear with an intercept of $1 / k_{1}$ and slope $1 / k_{1} K_{E}$. This was found to be the case at all temperatures studied. The $k_{1}$ and $K_{E}$ values were calculated from the intercept and slope (Figure 8 ) and are collected in Table 3.

4.2. Calculation of $k_{2}$ Value for Step $\boldsymbol{A} \rightarrow \boldsymbol{B}$. The rate constants for this path were calculated from the latter linear portions of the graphs and are collected in Table 2. This is again dependent on [dipeptide] and shows a limiting value at higher ligand concentrations. The intermediate here is also possibly stable through $\mathrm{H}$-bonding between coordinated water and the approaching dipeptide. When two paths are parallel, then two rates are overlapping. When we are calculating the $k_{1}$ 
TABLE 2: $10^{5} k_{2 \text { (obs) }}\left(\mathrm{s}^{-1}\right)$ values for different dipeptide concentrations at different temperatures; [Complex A $]=2.5 \times 10^{-4} \mathrm{~mol} \mathrm{dm}{ }^{-3}, \mathrm{pH}=4.3$, ionic strength $=0.1 \mathrm{~mol} \mathrm{dm}^{-3} \mathrm{NaClO}_{4}$.

\begin{tabular}{|c|c|c|c|c|c|c|}
\hline \multirow{2}{*}{ Ligand } & \multirow{2}{*}{ Temperature $\left({ }^{\circ} \mathrm{C}\right)$} & \multicolumn{5}{|c|}{$10^{3}$ [Ligand] $\left(\mathrm{mol} \mathrm{dm}^{-3}\right)$} \\
\hline & & 2.50 & 3.75 & 5.00 & 6.25 & 7.50 \\
\hline \multirow{4}{*}{$L^{1}-L^{\prime} H$} & 50 & 2.91 & 3.41 & 3.69 & 3.86 & 3.98 \\
\hline & 55 & 4.39 & 5.17 & 5.75 & 6.03 & 6.19 \\
\hline & 60 & 6.91 & 8.43 & 9.22 & 9.75 & 10.03 \\
\hline & 65 & 10.86 & 12.66 & 14.97 & 16.43 & 16.71 \\
\hline \multirow{4}{*}{$\mathrm{L}^{2}-\mathrm{L}^{\prime} \mathrm{H}$} & 50 & 2.71 & 3.08 & 3.34 & 3.50 & 3.57 \\
\hline & 55 & 4.22 & 4.93 & 5.38 & 5.71 & 5.99 \\
\hline & 60 & 6.37 & 7.69 & 8.55 & 9.09 & 9.26 \\
\hline & 65 & 9.98 & 12.50 & 13.51 & 14.29 & 16.10 \\
\hline \multirow{4}{*}{$L^{3}-L^{\prime} H$} & 50 & 2.79 & 3.22 & 3.51 & 3.65 & 3.76 \\
\hline & 55 & 4.24 & 5.00 & 5.56 & 5.85 & 6.06 \\
\hline & 60 & 6.58 & 8.06 & 8.85 & 9.35 & 9.62 \\
\hline & 65 & 10.64 & 12.50 & 14.29 & 15.87 & 16.13 \\
\hline
\end{tabular}

TABLE 3: The $k_{1}, k_{2}, K_{E}$, and $K_{E}^{\prime}$ values for different dipeptide concentration at different temperatures; [Complex $\left.\mathbf{A}\right]=2.5 \times 10^{-4} \mathrm{~mol} \mathrm{dm}^{-3}$, $\mathrm{pH}=4.3$, ionic strength $=0.1 \mathrm{~mol} \mathrm{dm} \mathrm{maClO}_{4}$.

\begin{tabular}{|c|c|c|c|c|c|}
\hline Ligand & Temperature $\left({ }^{\circ} \mathrm{C}\right)$ & $10^{3} k_{1}\left(\mathrm{~s}^{-1}\right)$ & $K_{E}\left(\mathrm{dm}^{3} \mathrm{~mol}^{-1}\right)$ & $10^{5} k_{2}\left(\mathrm{~s}^{-1}\right)$ & $K_{E}^{\prime}\left(\mathrm{dm}^{3} \mathrm{~mol}^{-1}\right)$ \\
\hline \multirow{4}{*}{$\mathrm{L}^{1}-\mathrm{L}^{\prime} \mathrm{H}$} & 50 & 5.25 & 295 & 4.92 & 330 \\
\hline & 55 & 6.15 & 309 & 7.94 & 433 \\
\hline & 60 & 7.26 & 315 & 13.38 & 498 \\
\hline & 65 & 8.51 & 319 & 23.93 & 580 \\
\hline \multirow{4}{*}{$\mathrm{L}^{2}-\mathrm{L}^{\prime} \mathrm{H}$} & 50 & 1.88 & 154 & 4.29 & 348 \\
\hline & 55 & 2.37 & 173 & 7.51 & 479 \\
\hline & 60 & 3.06 & 189 & 12.01 & 511 \\
\hline & 65 & 3.66 & 209 & 21.60 & 683 \\
\hline \multirow{4}{*}{$\mathrm{L}^{3}-\mathrm{L}^{\prime} \mathrm{H}$} & 50 & 3.55 & 304 & 4.60 & 359 \\
\hline & 55 & 4.50 & 331 & 7.82 & 428 \\
\hline & 60 & 5.08 & 413 & 12.85 & 475 \\
\hline & 65 & 6.21 & 429 & 22.31 & 616 \\
\hline
\end{tabular}

$\left(\sim 10^{-3} \mathrm{~s}^{-1}\right)$, the contribution from $k_{2}\left(10^{-5} \mathrm{~s}^{-1}\right)$ is negligible; and when we are calculating $k_{2}$, the $k_{1}$ path is already completed. Thus, there is no problem in calculating both the rate constants.

The $k_{2}$ and $K_{E}^{\prime}$ are calculated in a manner similar to (11), and data are collected in Table 3.

Based on the experimental findings, a two-step interchange associative mechanism is proposed for the substitution processes for both the paths. In the first step, an outersphere association complex is formed between the ligand and the two rhodium(III) centers, which is stabilized by the $\mathrm{H}$-bonding between the incoming dipeptide and the coordinated aqua molecules. Now the interchange of the ligand from the outer sphere to the inner sphere occurs.

Both the paths of the final phase of substitution reaction are the chelation step to give the product complex $(\mathbf{P})$ which is independent of dipeptide concentration.

4.3. Effect of $p H$ on Reaction Rate. The reaction was studied at five different $\mathrm{pH}$ values $(3.0,3.3,3.6,4.0$, and 4.3$)$. The $k_{1(\mathrm{obs})}$ and $k_{2(\mathrm{obs})}$ values increased with increase in $\mathrm{pH}$ at fixed concentration of $\left(2.5 \times 10^{-4} \mathrm{~mol} \mathrm{dm}^{-3}\right.$ of [complex A], $\left.7.50 \times 10^{-3} \mathrm{~mol} \mathrm{dm}^{-3}\left[\mathrm{~L}^{1}-\mathrm{L}^{\prime} \mathrm{H}\right]\right)$ and $0.1 \mathrm{~mol} \mathrm{dm}^{-3}$ ionic strength. The $10^{3} k_{1(\mathrm{obs})}$ values at $60^{\circ} \mathrm{C}$ were $2.59,3.17,3.81$, 4.46 and $5.15 \mathrm{~s}^{-1}$, and $10^{5} k_{2}$ values were $3.63,5.14,7.02,8.17$, and $10.03 \mathrm{~s}^{-1}$ at $3.0,3.3,3.6,4.0$, and 4.3 , respectively. The enhancement in rate may be explained based on the acid dissociation equilibria of the reactants. A rate expression for path 1 may be given as follows:

$$
\begin{aligned}
& k_{(\mathrm{obs})} \\
& =K_{1} K_{E} K_{c(1)} K_{a}[\text { dipeptide }]_{t}\left[\mathrm{H}^{+}\right] \\
& \times \\
& \quad\left(\left[\mathrm{H}^{+}\right]^{3}+\left[\mathrm{H}^{+}\right]^{2}\left(K_{a}+K_{c(1)}\right)+\left[\mathrm{H}^{+}\right]\right. \\
& \quad \times\left(K_{c(1)} K_{a}+K_{c(1)} K_{c(2)}+K_{c(1)} K_{a} K_{E}[\text { dipeptide }]_{t}\right) \\
& \left.\quad+K_{c(1)} K_{c(2)} K_{a}\right)^{-1}
\end{aligned}
$$

where $k_{1}$ and $K_{E}$ are rate constant and outer-sphere association equilibrium constant, and also $K_{c(1)}, K_{c(2)}$, and $K_{a}$ are acid dissociation constants of $\left[\mathrm{Rh}\left(\mathrm{H}_{2} \mathrm{O}\right)_{6}\right]^{3+}$, 
TABLE 4: Comparison of activation parameters for the interaction of different ligands with the complex in aqueous medium at $\mathrm{pH}=4.3$.

\begin{tabular}{|c|c|c|c|c|c|}
\hline Ligands & $\Delta H_{1}^{\neq}\left(\mathrm{kJ} \mathrm{mol}^{-1}\right)$ & $\Delta S_{1}^{\neq}\left(\mathrm{J} \mathrm{K}^{-1} \mathrm{~mol}^{-1}\right)$ & $\Delta H_{2}^{\neq}\left(\mathrm{kJ} \mathrm{mol}^{-1}\right)$ & $\Delta S_{2}^{\neq}\left(\mathrm{JK}^{-1} \mathrm{~mol}^{-1}\right)$ & Reference \\
\hline L-Arginine & $56.9 \pm 3.8$ & $-105 \pm 12$ & $89.1 \pm 2.9$ & $-54 \pm 9$ & {$[22]$} \\
\hline $\mathrm{L}^{1}-\mathrm{L}^{\prime} \mathrm{H}$ & $26.1 \pm 0.3$ & $-209 \pm 1$ & $91.3 \pm 2.9$ & $-45 \pm 9$ & This work \\
\hline $\mathrm{L}^{2}-\mathrm{L}^{\prime} \mathrm{H}$ & $37.2 \pm 0.7$ & $-183 \pm 2$ & $94.7 \pm 3.1$ & $-36 \pm 9$ & This work \\
\hline$L^{3}-L^{\prime} H$ & $29.4 \pm 2.8$ & $-201 \pm 8$ & $93.1 \pm 1.6$ & $-40 \pm 5$ & This work \\
\hline Glycyl-glycine & $26.7 \pm 0.3$ & $-207 \pm 1$ & $92.4 \pm 1.3$ & $-42 \pm 4$ & {$[23]$} \\
\hline Glycyl-L-glutamine & $34.7 \pm 1.3$ & $-189 \pm 4$ & $94.1 \pm 1.1$ & $-37 \pm 3$ & {$[24]$} \\
\hline Glycyl-L-valine & $22.0 \pm 1.2$ & $-220 \pm 4$ & $90.7 \pm 3.2$ & $-47 \pm 10$ & {$[24]$} \\
\hline
\end{tabular}

$\left[\mathrm{Rh}\left(\mathrm{H}_{2} \mathrm{O}\right)_{4}(\mathrm{OH})\right]^{2+}$, and for the ligand - $\mathrm{COOH}$, respectively. Further study of the substitution reaction was followed at $\mathrm{pH} 4.3$ to avoid complications caused by adding an additional parameter $\left[\mathrm{H}^{+}\right]$to the rate equation. At $\mathrm{pH} 4.3$, the complex exists mainly in the hydroxopentaaqua form, and the contribution due to the hexaaqua species is negligible. With increasing $\mathrm{pH}$, the complex also changes its form from aqua to hydroxoaqua, and the hydroxide ligand increases the water exchange rate constant of $\left[\mathrm{Rh}\left(\mathrm{H}_{2} \mathrm{O}\right)_{5}(\mathrm{OH})\right]^{2+}$ relative to $\left[\mathrm{Rh}\left(\mathrm{H}_{2} \mathrm{O}\right)_{6}\right]^{3+}$. However, the dipeptide acts as a buffer during the reaction.

4.4. Effect of Temperature on the Reaction Rate. The reaction was studied at four different temperatures for different ligand concentrations, and the results are listed in Tables 1 and 2. The activation parameters for both the paths were evaluated from the linear Eyring's plots and were collected in Table 4. The low $\Delta H^{\neq}$values were in support of the ligand participation in the transition state for both the steps. The high negative $\Delta S^{\neq}$values suggest a more compact transition state, where both the incoming and departing ligands are attached in the transition state, and this is also in support of the assumption of a ligand participated transition state.

\section{Mechanism and Conclusion}

Each dipeptide has one carboxyl group and one amino group at the opposite ends of the molecule. Because of neutrality of the amide group, the two terminal groups are the most effective bonding sites for metal coordination, but steric requirements preclude the simultaneous coordination of three groups to the same metal ion. Also tetra coordination complex formation may be possible when two metal ions are participated.

The complex of dipeptides such as glycyl-glycine with various metal ions has been studied. The metal ions, which are able to promote amide deprotonation, are the most interesting in this field. A literature survey [27] shows that $\mathrm{Pd}(\mathrm{II}), \mathrm{Cu}(\mathrm{II})$, and $\mathrm{Ni}(\mathrm{II})$ are most effective in this respect. There are reports of $\mathrm{Fe}(\mathrm{II})$ and $\mathrm{Fe}(\mathrm{III})$ induced deprotonation of the amide groups $[28,29]$.

Dipeptide may coordinate to $\mathrm{Rh}(\mathrm{III})$ ion in four way:

(1) monodentate coordination through carboxylate-O to give $1: 1$ and $1: 2$ products;
(2) bidentate coordination involving amino- $\mathrm{N}$ and carbonyl-O is expected to occur at low $\mathrm{pH}$ where amide deprotonation is difficult [30];

(3) tridentate coordination involving terminal carboxylate- $\mathrm{O}$, amide- $\mathrm{N}$, and amino- $\mathrm{N}$ groups gives rise to two fused five-membered rings. This has been observed with $\mathrm{Cu}(\mathrm{II}), \mathrm{Pd}(\mathrm{II})$, and $\mathrm{Ni}(\mathrm{II})$ complexes [27] in slightly alkaline medium;

(4) tetradentate coordination involving amino- $\mathrm{N}$, carbonyl-O, peptide- $\mathrm{N}$, and carboxylate-O gives a $2: 1$ (metal: ligand) five-membered chelated product of high stability [31]. This type of chelation occurs [32] at and above $\mathrm{pH} 4$.

As the substrate is a hydroxopentaaqua complex at experimental pH 4.3 and Job's method also confirms the formation of a 2:1 product, so the first three possibilities are ruled out. At first, the dipeptide binds to the rhodium center through carboxylate- $\mathrm{O}^{-}$and peptide- $\mathrm{O}$ which shows high affinity for $\mathrm{Rh}(\mathrm{III})$, a borderline acid. The carboxylate- $\mathrm{O}^{-}$has more electron density, and so it reacts at a faster rate than the other.

The interaction of dipeptide with the title rhodium complex proceeds via two distinct parallel substitution steps of aqua molecules $\left(k_{1} \sim 10^{-3} \mathrm{~s}^{-1}\right.$ and $\left.k_{2} \sim 10^{-5} \mathrm{~s}^{-1}\right)$. Each step proceeds via an associative interchange activation. At the outset of each step outer-sphere association complex results, which is stabilized through $\mathrm{H}$-bonding and is followed by an interchange from the outer-sphere to the inner-sphere complex. The outer-sphere association equilibrium constants, a measure of the extent of $\mathrm{H}$-bonding for each step at different temperatures, are evaluated (Table 3). The activation parameters for both the steps suggest an associative mode of activation for the substitution process. The $\Delta H_{1}^{\neq}$and $\Delta H_{2}^{\neq}$ values and negative $\Delta S_{1}^{\neq}$and $\Delta S_{2}^{\neq}$values imply a good degree of ligand participation in the transition state.

But for amino acids, the mechanism of substitution of aqua ligands in ion $\left[\mathrm{Rh}\left(\mathrm{H}_{2} \mathrm{O}\right)_{5}(\mathrm{OH})\right]^{2+}$ can be explained in terms of rapid outer-sphere association complex formation, followed by two consecutive steps; the first is dependent on ligand concentration, and second is the chelation, that is, ring closure step, which is independent of ligand concentration.

From a comparison of the dipeptides used, it can be concluded that the variation in size and bulkiness of the entering dipeptides reflects their properties as nucleophiles. The differences in reactivity of the selected dipeptides is 

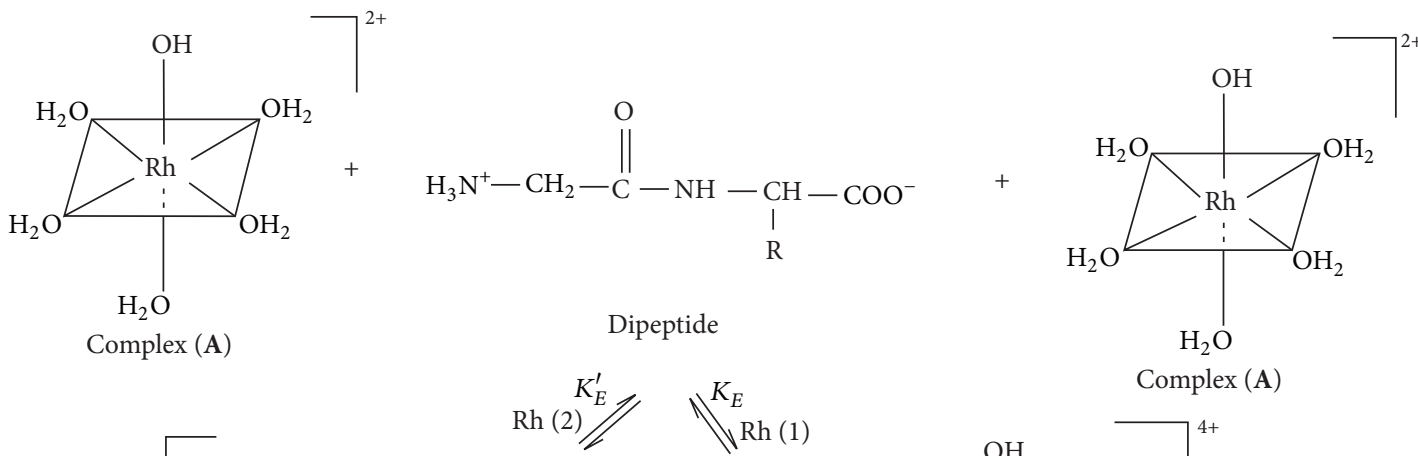

Complex (A)

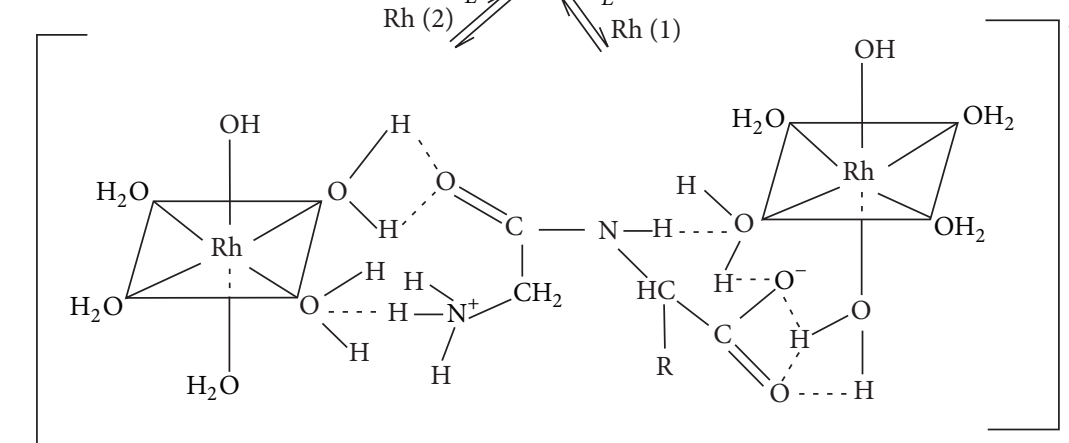

Outer-sphere association complex

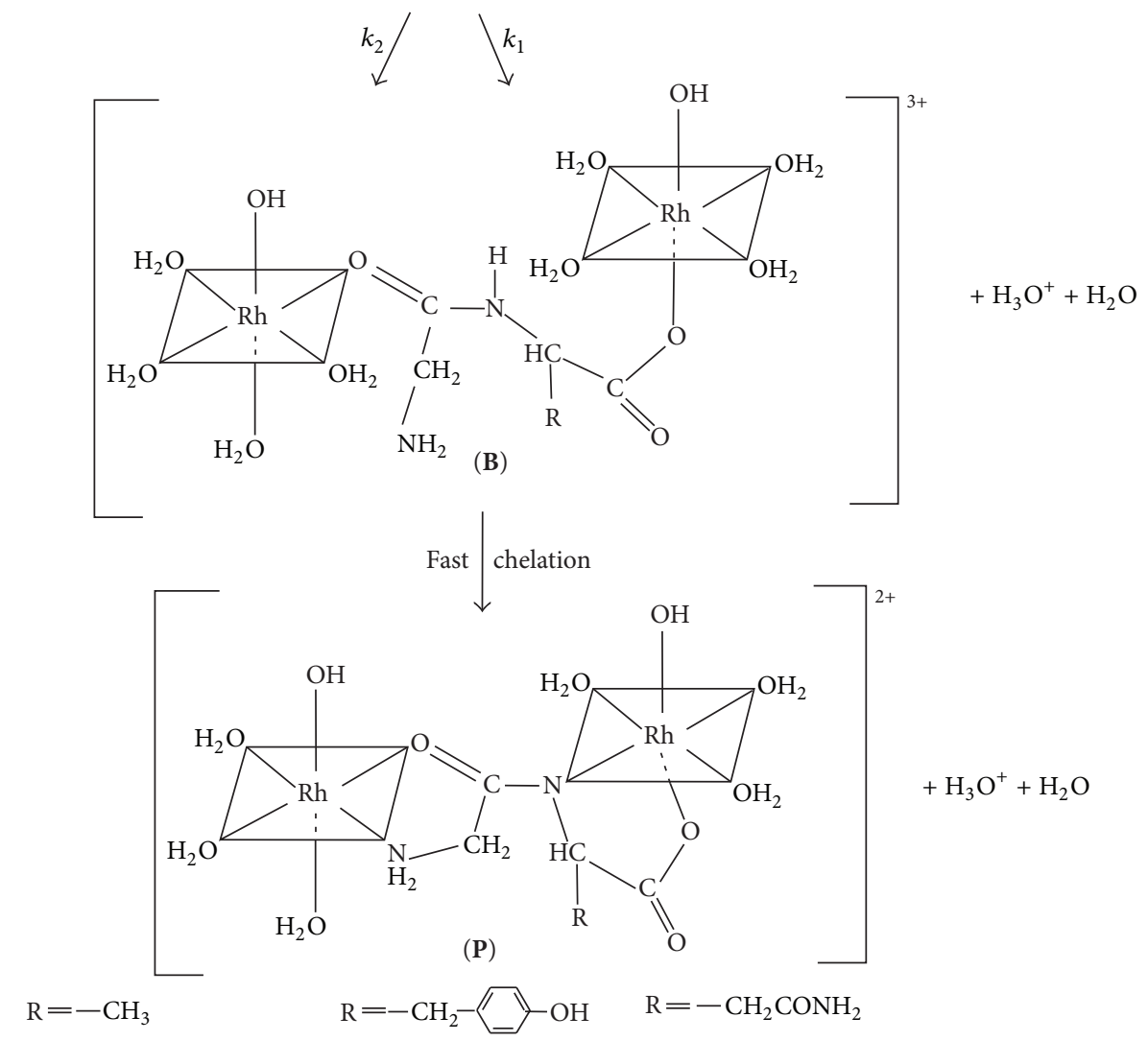

For glycyl-L-alanine

For glycyl-L-tyrosine

For glycyl-L-asparagine

FIGURE 9: Proposed mechanism for the interaction of dipeptide with the complex A.

obvious, and their reactivity follows the order $\mathrm{L}^{2}-\mathrm{L}^{\prime} \mathrm{H}<\mathrm{Gly}$ glut. $<\mathrm{L}^{3}-\mathrm{L}^{\prime} \mathrm{H}<$ Gly-gly. $<\mathrm{L}^{1}-\mathrm{L}^{\prime} \mathrm{H}<$ Gly-val. The sensitivity of the reaction rate towards the donor properties of the entering ligands is in line with that expected for an associative mode of activation. In addition, donor effects (present in different $\mathrm{R}$ group of dipeptide) were more important than steric effect due to the presence of water molecules in the hydroxopentaaquarhodium complex. Also the entering 
dipeptide was stabilized by hydrogen bonding with water molecules of hydroxopentaaquarhodium complex. For the three dipeptides with increasing donor effects, reactivity increases which is reflected in their rate constant values. Also, from ESI-MS measurement, a chelated product in the final step is proposed.

Based on the previous facts, a plausible mechanism for the substitution has been proposed as shown in Figure 9.

\section{References}

[1] B. P. Espósito and R. Najjar, "Interactions of antitumoral platinum-group metallodrugs with albumin," Coordination Chemistry Reviews, vol. 232, no. 1-2, pp. 137-149, 2002.

[2] D. Banerjee, T. A. Kadam, and H. Sigal, "Enhanced stability of ternary complexes in solution through the participation of heteroaromatic $\mathrm{N}$ bases. Comparison of the coordination tendency of pyridine, imidazole, ammonia, acetate, and hydrogen phosphate toward metal ion nitrilotriacetate complexes," Inorganic Chemistry, vol. 20, no. 8, pp. 2586-2590, 1981.

[3] D. R. Williams, "Anticancer drug design involving complexes of amino-acids and metal ions," Inorganica Chimica Acta, vol. 6, pp. 123-133, 1972.

[4] P. Köpf-Maier and H. Köpf, "Cytostatische platin-komplexe: eine unerwartete entdeckung mit weitreichenden konsequenzen," Naturwissenschaften, vol. 73, no. 5, pp. 239-247, 1986.

[5] M. Bień, T. M. Lachowicz, A. Rybka, F. P. Pruchnik, and L. Trynda, "Binuclear rhodium(II) complexes with selective antibacterial activity," Metal-Based Drugs, vol. 4, no. 2, pp. 8188, 1997.

[6] M. J. Clarke, "Oncological implications of the chemistry of ruthenium," Metal Ions in Biological Systems, vol. 11, pp. 231-283, 1980.

[7] R. E. Yasbin, C. R. Matthews, and M. J. Clarke, "Mutagenic and toxic effects of ruthenium," Chemico-Biological Interactions, vol. 31, no. 3, pp. 355-365, 1980.

[8] S. Wirth, C. J. Rohbogner, M. Cieslak et al., "Rhodium(III) and iridium(III) complexes with 1,2-naphthoquinone-1-oximate as a bidentate ligand: synthesis, structure, and biological activity," Journal of Biological Inorganic Chemistry, vol. 15, no. 3, pp. 429440, 2010.

[9] M. Dobroschke, Y. Geldmacher, I. Ott et al., "Cytotoxic rhodium (III) and iridium(III) polypyridyl complexes: structure-activity relationships, antileukemic activity, and apoptosis induction," ChemMedChem, vol. 4, no. 2, pp. 177-187, 2009.

[10] J. Reedijk, "The mechanism of action of platinum antitumor drugs," Pure and Applied Chemistry, vol. 59, no. 2, pp. 181-192, 1987.

[11] A. K. Ghosh, S. Ghosh, and G. S. De, "Displacement of aqua ligands from the hydroxopentaaquarhodium(III) ion by pyridine2-aldoxime: a kinetic and mechanistic approach," Transition Metal Chemistry, vol. 21, no. 4, pp. 358-362, 1996.

[12] A. K. Ghosh, S. Ghosh, and G. S. De, "Kinetics and mechanism of anation of hydroxopentaaquarhodium(III) ion by DLmethionine," Indian Journal of Chemistry A, vol. 35, no. 4, pp. 342-345, 1996.

[13] A. K. Ghosh, P. S. Sengupta, and G. S. De, "Interaction of 1cysteine with hydroxopentaaquarhodium(III) ion: kinetic and mechanistic studies," Indian Journal of Chemistry A, vol. 36, no. 7, pp. 611-613, 1997.
[14] A. K. Ghosh, "Kinetic and mechanistic studies on the interaction of adenosine with hydroxopentaaquarhodium(III) ion," Transition Metal Chemistry, vol. 23, no. 3, pp. 269-272, 1998.

[15] G. H. Ayres and J. S. Forrester, "The preparation of rhodium(III) perchlorate hexahydrate," Journal of Inorganic and Nuclear Chemistry, vol. 3, no. 6, pp. 365-366, 1957.

[16] W. C. Wolsey, C. A. Reynolds, and J. Kleinberg, "Complexes in the rhodium(III)-chloride system in acid solution," Inorganic Chemistry, vol. 2, no. 3, pp. 463-468, 1963.

[17] G. Pneumatikakis and N. Hadjiliadis, "Complexes of cysteine and cysteinemethylester with Pd(II) and Pt(II)," Journal of Inorganic and Nuclear Chemistry, vol. 41, no. 3, pp. 429-435, 1979.

[18] D. Steele and P. F. M. Verhoeven, "The vibrational spectrum and structure of cis- $\mathrm{Rh}\left(\mathrm{NH}_{3}\right)(\mathrm{CO})_{2} \mathrm{Cl}$," Vibrational Spectroscopy, vol. 25, no. 1, pp. 29-39, 2001.

[19] A. E. Martell and M. R. Smith, Critical Stability Constants-vol I: Amino Acids, vol. 1, Plenum Press, New York, NY, USA, 1974.

[20] I. Banyai, J. Glaser, M. C. Read, and M. Sandstroem, "Slow proton exchange kinetics in aqueous solutions of hexaaquarhodium(III): influence of the second hydration sphere," Inorganic Chemistry, vol. 34, no. 9, pp. 2423-2429, 1995.

[21] J. A. Weyh and R. E. Hamm, "Aquation of the cisbis(iminodiacetato)chromate(III) and trans(fac)bis(methyliminodiacetato)chromate(III) ions in acidic aqueous medium," Inorganic Chemistry, vol. 8, no. 11, pp. 2298-2302, 1969.

[22] B. K. Bera, S. Mallick, A. Mandal, P. Karmakar, A. K. Datta, and A. K. Ghosh, "Kinetics and mechanism of the reaction of hydroxopentaaquarhodium(III) ion with L-Arginine in aqueous solution," Transition Metal Chemistry, vol. 35, no. 5, pp. 541-547, 2010.

[23] B. K. Bera, S. Mallick, A. Mandal, S. Mondal, P. Karmakar, and A. K. Ghosh, "Interaction of glycyl-glycine with hydroxopentaaquarhodium(III) ion in aqueous medium: kinetic and mechanistic studies," Progress in Reaction Kinetics and Mechanism, vol. 36, no. 4, pp. 371-385, 2011.

[24] B. K. Bera, S. Mondal, S. Mallick, A. Mandal, P. Karmakar, and A. K. Ghosh, "Kinetic study of the interaction of three glycinecontaining dipeptides with hydroxopentaaquarhodium(III) ion in aqueous medium," Journal of Solution Chemistry, vol. 41, no. 4, pp. 741-753, 2012.

[25] G. A. Jeffrey, An Introduction to Hydrogen Bonding, Oxford University Press, Oxford, UK, 1997.

[26] G. R. Desiraju and T. Steiner, The Weak Hydrogen Bonding in Structural Chemistry and Biology, Oxford University Press, Oxford, UK, 1999.

[27] K. Burger, Biocoordination Chemistry, Coordination Equilibria in Biologically Active Systems, Ellis Horwood, Chichester, UK, 1996.

[28] R. J. Motekaitis and A. E. Martell, "New multidentate ligands. $\mathrm{X}$. Chelating tendencies of $\mathrm{N}, \mathrm{N}^{\prime}$-diglycylethylenediamine$\mathrm{N}^{\prime \prime}, \mathrm{N}^{\prime \prime}, \mathrm{N}^{\prime \prime \prime}, \mathrm{N}^{\prime \prime \prime}$-tetraacetic acid and ethylenediamine$\mathrm{N}-\mathrm{N}^{\prime}$ di(acetylglycine)-N, $\mathrm{N}^{\prime}$-diacetic acid," Journal of the American Chemical Society, vol. 92, no. 14, pp. 4223-4230, 1970.

[29] A.M. Bowles, W.A. Szarek, and M.C. Baird, "Nuclear magnetic resonance studies of the interactions of amino acids and peptides with ferrous ions," Inorganic and Nuclear Chemistry Letters, vol. 7, no. 1, pp. 25-28, 1971.

[30] A. M. Goswami and K. De, "Kinetic and mechanistic studies on the interaction between glycylglycine and cis-diaquabis-(bipyridine)-ruthenium(II) complex in aqueous medium," Transition Metal Chemistry, vol. 32, no. 4, pp. 419-424, 2007. 
[31] D. A. Buckingham, C. E. Davis, D. M. Foster, and A. M. Sargeson, "Cobalt (III)-promoted hydrolysis of chelated glycine amides, glycylglycine, and glycylglycine esters. Kinetics and mechanism," Journal of the American Chemical Society, vol. 92, no. 19, pp. 5571-5579, 1970.

[32] T. G. Appleton, J. R. Hall, T. W. Hambley, and P. D. Prenzler, "Reactions of the cis-diamminediaquaplatinum(II) cation with glycinamide, N-glycylglycine, and $\mathrm{N}$-(N-glycylglycyl)glycine. Crystal structure of a complex with two diammineplatinum(II) cations bound to glycylglycinate," Inorganic Chemistry, vol. 29, no. 18 , pp. 3562-3569, 1990. 

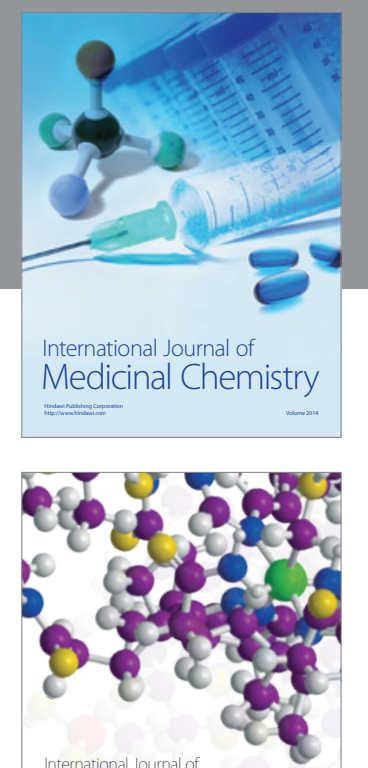

\section{Carbohydrate} Chemistry

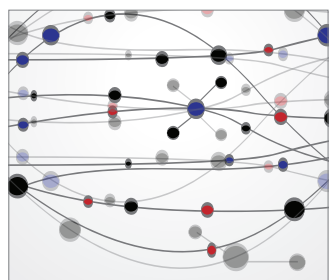

The Scientific World Journal
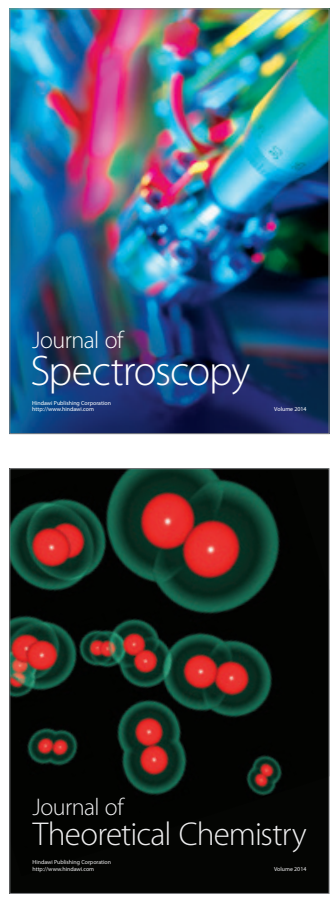
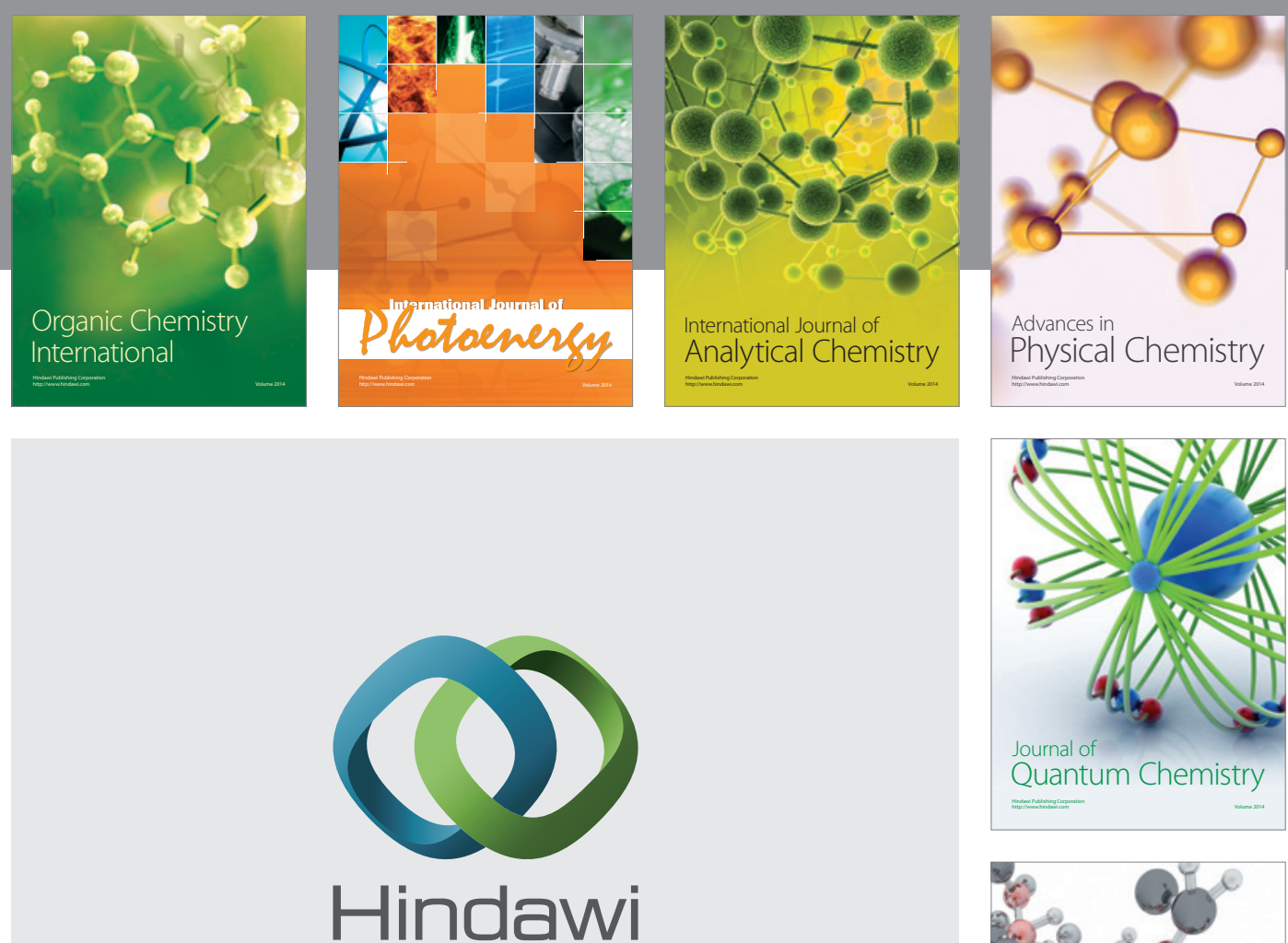

Submit your manuscripts at

http://www.hindawi.com

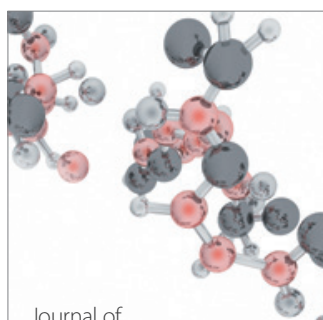

Analytical Methods

in Chemistry

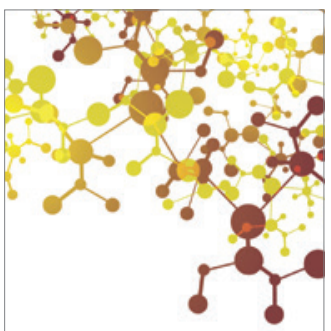

Journal of

Applied Chemistry

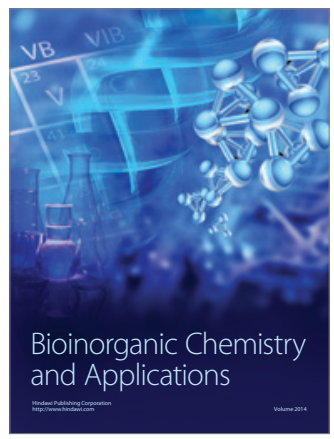

Inorganic Chemistry
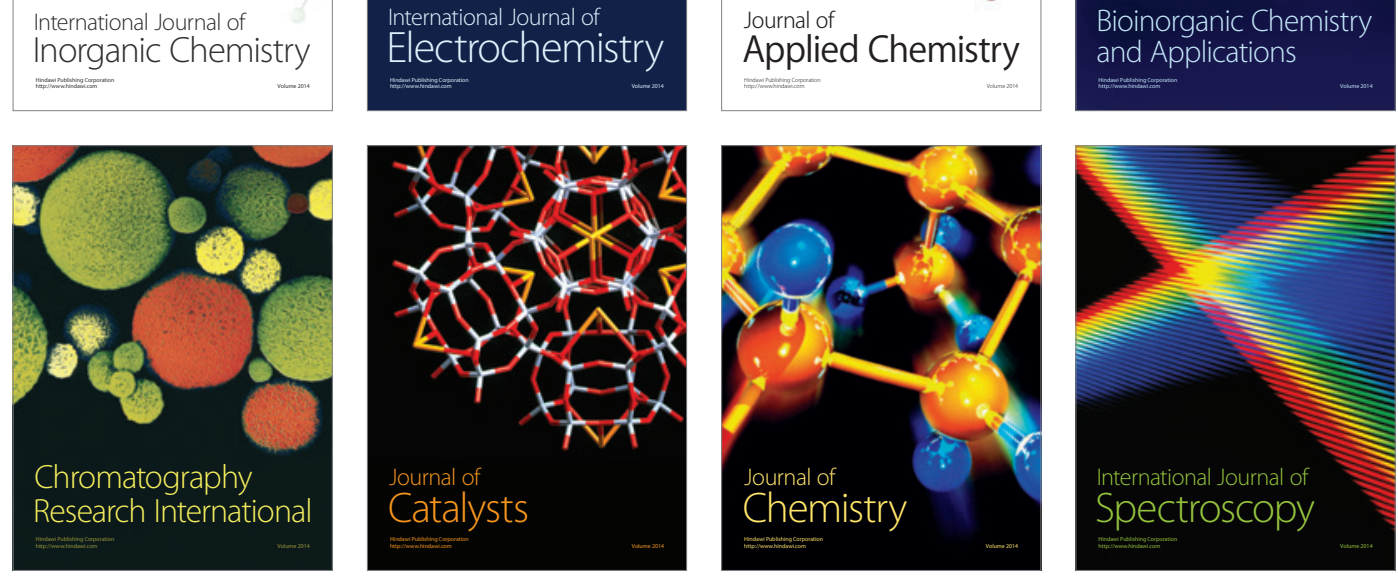